\title{
Transient Asymptomatic Bacteriuria in Infancy
}

\author{
G. D. ABBOTT,* M.B., M.R.A.C.P.
}

\begin{abstract}
Cummary : Spontaneous clearing of bacteriuria occurred in three infants during the neonatal and early infancy period. In all cases, the presence of bacteria was confirmed by bladder puncture, no signs of clinical infection were present, and no treatment was given. The same host defence mechanisms as exist in adults were probably responsible for this phenomenon.
\end{abstract}

\section{Introduction}

It is known that the bladder can rid itself of bacteria under normal circumstances. Clinical observations and laboratory studies in man (Cox and Hinman, 1961) and in animals (Cortran et al., 1963) have confirmed that when bacteria are introduced into the bladder they often disappear from the urine. Those instances in which the genitourinary tract fails to rid itself of bacteria may be regarded as a failure of host defence mechanisms. The two major host defence mechanisms are the mechanical clearing of organisms by voiding and the antibacterial activity of the bladder wall (Norden, Green, and Kass, 1968).

No reports of spontaneous clearing of bacteria from the bladder of neonates or infants are known to have been made previously. Three cases are reported in which this phenomenon took place.

\section{Methods of Study}

In a study of the incidence and natural history of bacteriuria in the neonatal period in 1,500 infants it was noted that transient bacteriuria occurred. In every instance the presence of bacteriuria was established by bladder puncture by a similar method to those described by Pryles (1965), Bailey and Little (1969), and Shannon et al (1969). After the first bladder puncture a variable period elapsed before the procedure was repeated. The infants were closely observed in the interim period for the development of symptoms which might indicate clinical infection.

In all the infants who developed bacteriuria in the study the urine was examined by microscopy for leucocytes and by Albustix for the presence of protein. Blood culture and blood urea estimations were performed; and intravenous pyelography and micturating cystourethrography carried out.

\section{Clinical Reports}

Case 1.-A normal full-term male infant had a "clean catch" urine specimen collected at the age of five days. The specimen was cultured by a standard bacteriological technique and 200,000 Gram-negative organisms $/ \mathrm{ml}$. grew on the culture plate. Bladder puncture was performed on the sixth day and a heavy growth of Escherichia coli resulted. The urine contained no protein or leucocytes. The blood urea was $25 \mathrm{mg} . / 100 \mathrm{ml}$. and the blood culture was sterile. Further bladder punctures were performed at 12 and 17 days of age and the cultures grew 20,000 and $14,000 \mathrm{E}$. coli $/ \mathrm{ml}$., respectively. The urine at 21 days of age was sterile on bladder puncture and contained no protein or leucocytes. The infant thrived during this bacteriuric period, without any symptoms to suggest urinary infection. Treatment was not given during this period. On radiological examination at the age of three-and-ahalf weeks the intravenous pyelogram was normal but the micturating cystourethrogram showed free bilateral vesicoureteric re-

* Senior Paediatric Registrar, Christchurch Hospital, Christchurch, New Zealand. flux. The infant has remained free of infection on follow-up over one year.

Case 2.-A normal full-term female infant had a "clean catch" urine collection performed at the age of four days. The culture grew 50,000 mixed organisms $/ \mathrm{ml}$. with a predominant growth of a Gram-negative organism. Bladder puncture was performed at the age of seven days and the culture grew a heavy growth of an Enterobacter species and Streptococcus viridans. Bladder puncture was repeated at $\mathbf{1 4}$ days of age; the urine was sterile and contained no leucocytes or protein. The blood urea was $30 \mathrm{mg} . / 100 \mathrm{ml}$. and blood culture was sterile. The infant remained asymptomatic throughout and showed a satisfactory weight gain. At follow-up at the age of 16 weeks bacteriuria was again noted on bladder puncture, the colony count being $100,000 \mathrm{E}$. coli/ml. After a symptom-free interval of five days urine obtained by bladder puncture was again sterile and contained 0-2 leucocytes/cu.mm. but no protein. Treatment was not given during these bacteriuric periods. On radiological examination the intravenous pyelogram was normal, but the micturating cystourethrogram showed free bilateral reflux. The infant has remained free of infection over 14 months.

Case 3.-A three-week-old male infant was admitted to hospital for investigation of his genitourinary tract because a single umbilical artery had been found at the time of birth. No other congenital abnormalities were apparent on clinical examination. On bladder puncture the urine was sterile and contained 5 leucocytes/cu.mm. and no protein. The intravenous pyelogram and the micturating cystourethrogram were both normal. Urine obtained by bladder puncture 36 hours after the cystogram grew 80,000 E. coli $/ \mathrm{ml}$. but contained no protein or leucocytes. Bladder puncture was repeated five days later, when the urine was sterile. The infant remained well, no treatment being given. No further infections have occurred.

\section{Discussion}

The urinary bladder of the neonate and infant is capable of ridding itself of bacteria, presumably by the same mechanisms as exist in the adult. Failure of this host defence mechanism presumably leads to persistent bacteriuria and clinical infection. It is likely that bacteria gain access to the bladder via the urethra, though there is no definite proof of this.

In the first two cases reported the genitourinary tracts were not normal, and in the third case bacteria were probably introduced during catheterization for the cystourethrogram. In all three infants, however, vesical emptying was complete and bacteria did not persist in the bladder. Moreover, these bacteria did not produce clinical infection.

The incidental finding of bacteriuria in an otherwise healthy infant may thus be a transient phenomenon only. Provided local defence mechanisms are intact and tissue invasion does not occur, the relative immunological immaturity in this age group may not be so important.

I wish to thank Dr. F. T. Shannon for allowing me to study these infants under his care, and for his continuing encouragement. I also wish to thank Glaxo Laboratories for financial assistance.

\section{REFERENCES}

Bailey, R. R., and Little, P. J. (1969). British Medical foumal, 1, 293.

Cortran, R. S., et al. (1963). fournal of Laboratory and Clinical Medicine, 61, 987.

Cox, C.; and Hinman, F. (1961). Fournal of Urology, 86, 739.

Norden, C. W., Green, G. M., and Kass, E. H. (1968). Fournal of Clinical Investigation, 47, 2689.

Pryles, C. V. (1965). Pediatrics, 36, 128.

Shannon, F. T., Sepp, E., and Rose, G. R. (1969). Australian Paediatric fourmal, 5, 97 